\title{
Gambaran Hematologi Pascatransfusi Darah pada Anjing yang Mengalami Babesiosis
}

\author{
Ni Wayan Linda Pertiwi*, Anak Agung Istri Inten \\ Listriani Vet Care Jalan Tukad Balian No 882 Sidakarya, Denpasar
}

ABSTRAK: Babesiosis merupakan salah satu penyakit yang menginduksi timbulnya anemia pada anjing. Anemia berat dapat ditangani melalui tranfusi darah. Gambaran hematologi darah harus dievaluasi pasca tranfusi untuk memastikan keberhasilam tranfusi. Anemia regenerative akan merespon tranfusi darah sekitar dua minggu pasca tranfusi dilakukan, ditandai dengan menurunnya indikator infeksi dan kembalinya jumlah sel darah merah mendekati normal.

Kata kunci:

anemia, babesiosis, tranfusi darah

\section{- PENDAHULUAN}

Babesiosis adalah salah satu penyakit protozoa yang ditularkan melalui gigitan caplak. Penyakit ini ditandai dengan gejala klinis berupa anemia hemolytic, trombositopenia, demam, dan splenomegaly (Solano-Gallego dan Baneth 2011). Beberapa jenis spesies babesia yang secara klinis dapat menyebabkan munculnya gejala sakit pada anjing diantaranya adalah Babesia gibsoni, Babesia conradae dan Babesia vulpes (Eichenberger 2017).

\section{- ANAMNESIS DAN SINYALEMEN}

Seekor anjing Golden Retriever jantan yang berumur 5 tahun dengan berat $30,5 \mathrm{~kg}$ datang ke klinik dalam kondisi yang sangat lemah, tidak bisa berdiri, tidak mau makan, dan banyak ditemukan caplak di seluruh badan. Hewan mulai menunjukkan tanda-tanda sakit sejak dua hari terakhir sebelum datang ke klinik dengan gejala awal berupa perut terasa panas saat diraba. Riwayat penggunaan antiparasit tidak dilakukan secara rutin pada anjing ini. Vaksinasi hanya dilakukan sekali saat anjing berumur muda.

\section{- GEJALA KLINIS}

Hewan dirawat inap di klinik karena kondisi lethargy, loss appetite, dan mukosa mata dan mulut pucat. Hasil pemeriksaan darah lengkap menunjukkan hewan mengalami anemia berat. Leukositosis terjadi ditandai dengan adanya peningkatan jumlah sel darah putih $\left(29,81 \times 10^{3} / \mathrm{ul}\right)$. Sel darah merah $2,89 \times 10^{6} / \mathrm{ul}$ dan PCV10,76\%, sementara nilai trombosit berada di angka $161 \times 10^{3} /$ ul. Selain itu dilakukan uji ulas darah untuk mengetahui morfologi sel darah. Hasil pemeriksaan ulas darah ditemukan adanya parasit darah Babesia sp. sebagaimana disajikan pada Gambar 1 .

\section{- HASIL DAN PEMBAHASAN}

Babesia hidup secara intraseluler, merusak sel darah merah hewan penderita dan mengakibatkan anemia hemolytic dan trombositopenia (Solano-Gallego dan Baneth 2011). Hewan dikategorikan anemia berat jika sel darah merah berada di bawah $3 \times 10^{6} /$ ul dan PCV di bawah $15 \%$. Anemia menyebabkan timbulnya penurunan kadar oksigen darah (hypoxaemia) yang menginduksi kidney dan liver failure serta systemic inflammatory disease (Sodikoff 2001). Oleh sebab itu, transfusi darah harus dilakuan dengan cepat pada saat hewan terdiagnosa anemia.

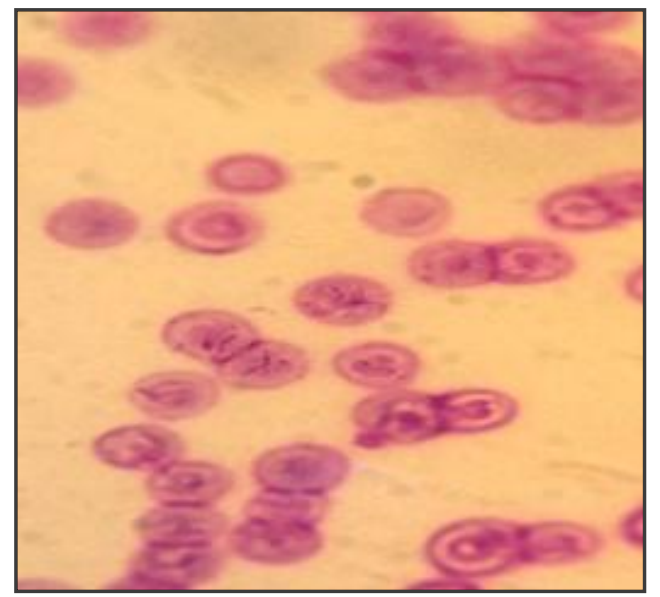

Gambar 1. Hasil ulas darah ditemukan parasit Babesia sp (pembesaran $1000 \times$ pada pewarnaan giemsa)

\footnotetext{
Diterima : 28 Juli 2017

Direvisi : 14 Agustus 2017

Disetujui : 16 Agustus 2017
} 
Tabel 1 Hasil pemeriksaan darah anjing Golden Retriever sebelum dan sesudah dilakukan transfusi darah

\begin{tabular}{lcccc}
\hline \multicolumn{1}{c}{ Parameter } & Sebelum transfusi darah & $\mathbf{4 8}$ jam post transfusi & $\mathbf{1 ~ m i n g g u ~ p o s t ~ t r a n s f u s i ~}$ & 2 minggu post transfusi \\
\hline Leukosit $\left(10^{3} / \mathrm{ul}\right)$ & $29,81 \mathrm{H}$ & $26,43 \mathrm{H}$ & $21,02 \mathrm{H}$ & $20,07 \mathrm{H}$ \\
Limfosit $\left(10^{3} / \mathrm{ul}\right)$ & 4,44 & 2,96 & $5,56 \mathrm{H}$ & 2,99 \\
Monosit $\left(10^{3} / \mathrm{ul}\right)$ & 0,70 & 1,00 & 0,29 & 0,82 \\
Neutrofil $\left(10^{3} / \mathrm{ul}\right)$ & $24,34 \mathrm{H}$ & $22,42 \mathrm{H}$ & $15,07 \mathrm{H}$ & $20,15 \mathrm{H}$ \\
Eosinofil $\left(10^{3} / \mathrm{ul}\right)$ & 0,24 & 0,04 & 0,06 & 0,74 \\
Basofil $\left(10^{3} / \mathrm{ul}\right)$ & 0,10 & 0,01 & 0,04 & 0,38 \\
Eritrosit $\left(10^{6} / \mathrm{ul}\right)$ & $2,89 \mathrm{~L}$ & $2,90 \mathrm{~L}$ & $4,37 \mathrm{~L}$ & $5,13 \mathrm{~L}$ \\
Hemoglobin $(\mathrm{g} / \mathrm{dl})$ & $3,7 \mathrm{~L}$ & $3,9 \mathrm{~L}$ & $6,5 \mathrm{~L}$ & $7,3 \mathrm{~L}$ \\
Hematokrit $(\%)$ & $10,76 \mathrm{~L}$ & $13,89 \mathrm{~L}$ & $20,16 \mathrm{~L}$ & $22,37 \mathrm{~L}$ \\
MCV $(\mathrm{fl})$ & $37 \mathrm{~L}$ & $50 \mathrm{~L}$ & $46 \mathrm{~L}$ & $44 \mathrm{~L}$ \\
MCH $(\mathrm{pg})$ & $12,9 \mathrm{~L}$ & $13,8 \mathrm{~L}$ & $15,0 \mathrm{~L}$ & $14,2 \mathrm{~L}$ \\
MCHC $(\mathrm{g} / \mathrm{dl})$ & $34,7 \mathrm{~L}$ & $27,9 \mathrm{~L}$ & 32,4 & 32,7 \\
Trombosit $\left(10^{3} / \mathrm{ul}\right)$ & $161 \mathrm{~L}$ & $192 \mathrm{~L}$ & 425 & 513 \\
\hline
\end{tabular}

\section{Keterangan:}

$\mathrm{MCV}=$ mean corpuscular volume, $\mathrm{MCH}=$ mean corpuscular hemoglobin, $\mathrm{MCHC}=$ mean corpuscular hemoglobin concentration, $\mathrm{H}=\mathrm{lebih}$ dari rentang normal, $\mathrm{L}=$ kurang dari rentang normal

Masa hidup sel darah merah berkisar 120 hari dan terjadi keseimbangan antara proses pembentukan dan penghancurannya (Schaer 2010). Pada kasus ini, sel darah merah meningkat 48 jam post transfusi, namun belum tampak signifikan. Sel darah merah mulai meningkat drastis 1 minggu post transfusi, dan mendekati normal 2 minggu post transfusi (Tabel 1).

\section{- SIMPULAN}

Babesiosis menyebabkan timbulnya leukositosis dan anemia berat pada hewan. Tranfusi darah diperlukan untuk meningkatkan jumlah sel darah merah padahewan penderita. Dibutuhkan waktu sekitar 2 minggu untuk membuat level sel darah merah dan sel darah putih kembali ke angka normal.

\section{- INFORMASI PENULIS}

Penulis untuk Korespondensi pertiwilind@gmail.com

\section{- PUSTAKA ACUAN}

Eichenberger RM, Štefanić S, Naucke TJ, Šarkūnas M, Zamokas G, Grimm F, Deplazes P. 2017. An ELISA for the early diagnosis of acute canine babesiosis detecting circulating antigen of large Babesia spp. Veterinary Parasitology. 243: 162-168.

Schaer M. 2010. Clinical medicine of the dog and cat. London (UK): CRC Press.

Sodikoff CH. 2001. Laboratory profiles of small animal diseases: a guide to laboratory diagnosis $3^{\text {rd }}$ edition. St Louis (US): Mosby Inc.

Solano-Gallego L, Baneth G. 2011. Babesiosis in dogs and catsexpanding parasitological and clinical spectra. Veterinary parasitology. 181(1): 48-60. 